\title{
糖尿病性腎症をはじめとした血液透析患者の緊急手術の検討と対策
}

\author{
添田耕司小高通夫* 田畑陽一郎磯野可一 \\ 嶋田 俊恒** 西 島 浩** 豊泉 惣一郎** \\ 千葉大学第 2 外科 同人工腎臟部* 千葉社会保険病院 ${ }^{* *}$ \\ (平成 1 年 12 月 6 日受付, 同 2 年 2 月 20 日受理)
}

key words: hemodialysis patients, emergency operation, diabetic nephropathy, non-heparin hemodialysis, nafamostat mesilate

〈要旨〉

1966 年 9 月より 1989 年 6 月まで当施設で曼性維持透析患者の併存病変に対して施行した緊急手術 72 例, 待期手術

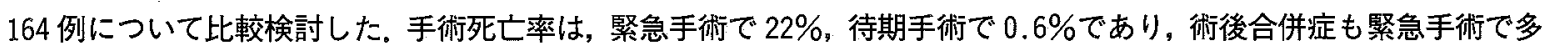
かった，最近，糖尿病性腎症例の緊急手術例を 3 例経験したが，全例に術前合併症を認め，術後合併症も心不全や感 染症を全例に認めた，糖尿病性腎症緊急手術例では，特に水分管理と院内感染予防が重要である. 低分子へパリンを 用いた術後初回透析で凝固時間の延長と後出血を認めず十分に施行できた。術後透析および術直前透析では, 低分子 ヘパリンや nafamostat mesilate を用いた透析か, EVA 膜少ヘパリン透析が有用である。沉発性腹膜炎等では手術 にて感染および壊死巣を除去し, その後透析を行い, 上部消化管穿孔等では, 前日透析してあれば即手術を, 前々日 の透析であれば透析後に手術をするのがよいと考えている.

\section{Evaluation and surgical management of emergency operation, including that for diabetic nephropathy, in hemodialysis patients}

Kouji Soeda, M. D., Michio Odaka, M. D.*, Yoichiro Tabata, M. D., Kaichi Isono, M. D., Toshitsune Shimada, M. D.**, Hiroshi Nishijima, M. D.**, Soichiro Toyoizumi, M. D.**

Second Department of Surgery, and Dialysis Center of Chiba University Hospital*, Chiba University School of Medicine ; Chiba Shakai Hoken Hospital**

In this study we evaluated 72 emergency operations and 164 elective operations performed on hemodialysis patients in our institutes from September 1966 to June 1989. Death rates within one month after surgery were $22 \%$ for emergency cases and $0.6 \%$ for elective cases. The emergency cases had postoperative complications such as sepsis and respiratory failure.

We experienced 3 cases of diabetic nephropathy among the emergency operations. They all had complications both before and after surgery. Complications after surgery were mainly heart failure and infections. Therefore, we stress the importance of managing water balance and preventing cross infection in hospital.

Hemodialysis after surgery was successfully performed without prolongation of coagulation time and bleeding using low molecular heparin. Low molecular heparin and nafamostat mesilate were available for hemodialysis before and after surgery as anticoagulant drugs. An EVA membrane dialyzer was also useful for hemodialysis before and after surgery.

透析患者の併存病変に対する手術は, 一般に行われる ようになってきており，医師の立場1)，看護婦の立場2)か ら，術後合併症をいかに減らすかという努力がなされて いる。また臨床外科医学会総会では，第 49 回総会 $(1987$

添田 耕司 千葉大学第 2 外科

干 280 千葉市亥鼻 1-8-1（0472-22-7171）
年）と第 51 回総会（1989 年）において，透析外科 ${ }^{3)}$ とい うセッションができた。

このように一般的になってきた透析患者の手術である が, 我々が 1986 年に指摘 ${ }^{4}$ したように緊急手術に対する 対策が未だ不十分であり，とくに近年の糖尿病性腎症例 の増加 ${ }^{5,6)}$ によるその緊急手術例に対しては，今後検討を 
表 1 慢性透析患者手術症例（1） 千葉大 2 外, 千葉社保 1966.9 1989.6

\begin{tabular}{|c|c|c|c|}
\hline 原 疾 患 & 術 & 症例数 & 直死例数 \\
\hline 消化器系疾患 & & $79(45)$ & $9(9)$ \\
\hline 舌, 癌 & 舌部分切除術 & 1 & \\
\hline 食道異物 & 食道切開術 & $1(1)$ & \\
\hline 食道癌 & $\begin{array}{l}\text { 胸部食道全摘, 噴門切除, 胸壁 } \\
\text { 前食道署吻合術 }\end{array}$ & 1 & \\
\hline 罢十二指腸潰瘍 & 胃切除術 & $2(2)$ & \\
\hline 十二指腸潰湯穿孔 & 胃切除・ドレナージ術 & $1(1)$ & \\
\hline 吻合部潰瘍 & 残胃再切除術 & $1(1)$ & $1(1)$ \\
\hline 青 癌 & 胃切除・大網切除術 & 13 & \\
\hline 胆石症 & 胆囊摘出術 & 2 & \\
\hline 胆囊炎 & 阳囊摘出術 & $1(1)$ & \\
\hline 胆囊ポリープ & 㫜囊摘出術 & 1 & \\
\hline 胆霻・結腸重複癌 & 胆囊摘出・胆管合併切除術 & 1 & \\
\hline 小腸脂肪腫 & 回腸部分切除 & $1(1)$ & \\
\hline 腸間膜血腫 & 開腹止血術 & $1(1)$ & \\
\hline 盲腸炎 & 回盲部切除 & 1 & \\
\hline 腹壁ヘルニア & 根治術 & 1 & \\
\hline 虫垂炎 & 虫垂切除術 & $16(16)$ & $1(1)$ \\
\hline 腹膜炎 & ドレナージ術 & $7(7)$ & $3(3)$ \\
\hline 腸閉塞症 & 癋着剝離術 & $7(7)$ & $2(2)$ \\
\hline 結腸軸捻転 & $\mathrm{S}$ 状結腸切除 & $1(1)$ & \\
\hline 上腸間膜動脈血栓症 & 試験開腹 & $2(2)$ & $2(2)$ \\
\hline 虫垂癌 & 虫垂切除術 & $1(1)$ & \\
\hline 虫垂癌・肝転移 & 回結腸吻合術 & 1 & \\
\hline 肝細腔㿔 & 肝外側区域切除術 & 1 & \\
\hline 結腸癌 & 結腸切除術 & 1 & \\
\hline 直腸癌 & 腹会陰式直腸切断術 & 1 & \\
\hline 直腸癌 & 低位前方切除術 & 1 & \\
\hline 痔 核 & 根治術 & $9(2)$ & \\
\hline 腸結核 & 試験開腹 & 1 (1) & \\
\hline
\end{tabular}

重ねなければならない問題がある。今回我々は，透析患 者の緊急手術成績を示し, 糖尿病症例を呈示して, その 問題点と対策について検討する.

\section{対象および方法}

1966 年 9 月より 1989 年 6 月までに千葉大学第 2 外科 および千葉社会保険病院に括いて経験した慢性透析患者 の併存病変手術例は 236 例であり，このうち緊急手術は 72 例であった。待期手術例と緊急手術例を対比し, 手術 成績, 術後合併症および術前検查成績について検討した。 さらに最近経験した緊急手術症例 4 例を呈示し, その原 疾患, 手術疾患, 手術術式, 術前合併症, 転帰について 検討した。

また維持透析例 4 例と維持透析患者手術症例の術後初 回透析において，低分子へパリンを投与し，アクスター 法による凝固時間 $(\mathrm{ACT})$ を, 透析前, 術後症例では透 析後 1,3 時間においてシャント対側の静脈血を採取し 測定し，透析開始後 1 時間と終了直前では，回路内の低
分子ヘパリン注入口より動脈側と静脈側において測定し た. 術後症例は, 胃癌胃切除 2 例, 虫垂癌回結腸吻合 1 例, 直腸癌直腸切断例 1 例であった. 低分子へパリンは, 開始量 $500 \mathrm{U}$, 維持量 $250 \mathrm{U} /$ 時で, ACT 法の正常者の 值は $107 \pm 4$ 秒，透析患者では 90〜130秒である7).また 食道癌の待期根治術例の術後初回透析で mafamostat mesilate (FUT-175, フサン®) を開始量 $20 \mathrm{mg}$, 維持量 $20 \mathrm{mg} /$ 時投与し, ACT 法で凝固時間を低分子へパリン と同様に測定した。

\section{結果}

1. 待期手術と緊急手術の手術成績

手術例数は, 消化器系 79 例, 心脈管系 19 例等で計 236 例であった(表 1 ～3)。このうち緊急手術症例は, 消化 器系 45 例を含む 72 例であった（表 4 ）.

手術死亡率は, 緊急手術で 72 例中 16 例 $22 \%$ であるの に対し, 待期手術では 164 例中 1 例 $0.6 \%$ と緊急手術例 で高頻度であった。腹部全麻例でも, 手術死亡率は, 緊 
表 2 慢性透析患者手術症例（2） 千葉大 2 外, 千葉社保 1966.9 1989.6

\begin{tabular}{|c|c|c|c|}
\hline 原 疾 患 & 術 & 症例数 & 直死例数 \\
\hline 心脈管系疾患 & & $19(18)$ & $3(3)$ \\
\hline $\begin{array}{l}\text { 心包炎・心タンポナーデ } \\
\text { 鎖骨下静脈血栓症 } \\
\text { 腋窩動脈瘤 }\end{array}$ & $\begin{array}{l}\text { 心包ドレナージ術 } \\
\text { 血栓除去乪 } \\
\text { 上肢切断術 }\end{array}$ & $\begin{array}{r}17(17) \\
1(1) \\
1\end{array}$ & $3(3)$ \\
\hline 泌尿器系疾患 & & $19(3)$ & $1(1)$ \\
\hline $\begin{array}{l}\text { 悪性高血压 } \\
\text { 囊胞腎 } \\
\text { 腎結石 } \\
\text { 腎結核・水腎症 } \\
\text { 膿腎症 } \\
\text { 腎 癌 } \\
\text { 膀胱出血 } \\
\text { その他 } \\
\end{array}$ & $\begin{array}{l}\text { 両側腎摘出術 } \\
\text { 腎摘出術 } \\
\text { 腎切開術 } \\
\text { 腎摘出術 } \\
\text { 腎摘出術 } \\
\text { 腎摘出術 } \\
\text { 膀胱切開, 骨片除去術 }\end{array}$ & $\begin{array}{ll}3 & \\
5 & \\
1 & \\
1 & \\
1 & (1) \\
3 & \\
2 & (2) \\
3 & \\
\end{array}$ & $1(1)$ \\
\hline 整形外科系疾患 & & $30(2)$ & $2(2)$ \\
\hline $\begin{array}{l}\text { 手根管症候群 } \\
\text { 大腿骨頸部骨折 } \\
\text { 人工骨頭置換後膿瘍 } \\
\text { その他 }\end{array}$ & $\begin{array}{l}\text { 根治術 } \\
\text { 人工骨頭置換術 } \\
\text { 人工骨頭抜去術 }\end{array}$ & $\begin{array}{r}17 \\
5 \\
1 \\
7 \quad(2) \\
\end{array}$ & $2(2)$ \\
\hline 眼科系疾患 & & 18 & \\
\hline $\begin{array}{l}\text { 白内障 } \\
\text { 緑内障 } \\
\text { 縦膜剝離 }\end{array}$ & $\begin{array}{l}\text { レンズ摘出術 } \\
\text { 隅角切開術 } \\
\text { ジアテルミー }\end{array}$ & $\begin{array}{r}12 \\
1 \\
5\end{array}$ & \\
\hline
\end{tabular}

表 3 慢性透析患者手術症例（3） 千葉大 2 外, 千葉社保 1966.9 1989.6

\begin{tabular}{|c|c|c|c|}
\hline 原 疾 患 & 術 & 症例数 & 直死例数 \\
\hline 産・婦人科系疾患 & & $11(1)$ & \\
\hline 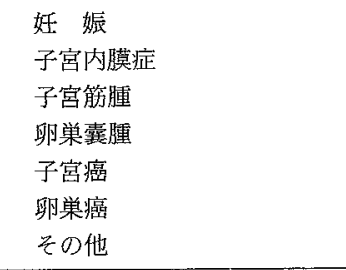 & $\begin{array}{l}\text { 帝王切開術 } \\
\text { 膣上部切断術・卵宩摘出術 } \\
\text { 膣上部切断術 } \\
\text { 卵巣摘出術 } \\
\text { 子宮全摘術 } \\
\text { 卵栄摘出術 }\end{array}$ & $\begin{array}{ll}1 & (1) \\
1 & \\
3 & \\
1 & \\
1 & \\
1 & \\
3 & \end{array}$ & \\
\hline 脳外科系疾患 & & $3(3)$ & $1(1)$ \\
\hline 硬膜下 (外) 血腫 & 開頭術 & $3(3)$ & $1(1)$ \\
\hline 内分泌系疾患 & & 8 & \\
\hline $\begin{array}{l}\text { 続発性上皮小体機能元進症 } \\
\text { 甲状腺癌 } \\
\text { 乳 癌 } \\
\text { 褐色細胞腫 } \\
\text { 甲状腺賈腫 }\end{array}$ & $\begin{array}{l}\text { 上皮小体全摘・自家移植術 } \\
\text { 甲状腺亚全摘術 } \\
\text { 乳房切断術 } \\
\text { 副腎摘出術 } \\
\text { 囊腫摘出術 }\end{array}$ & $\begin{array}{l}3 \\
2 \\
1 \\
1 \\
1\end{array}$ & \\
\hline 耳鼻科系疾患 & & 2 & \\
\hline $\begin{array}{l}\text { 内耳炎 } \\
\text { 頸部結核 }\end{array}$ & $\begin{array}{l}\text { 鼓室形成術 } \\
\text { 膿瘍摘出術 }\end{array}$ & $\begin{array}{l}1 \\
1 \\
\end{array}$ & \\
\hline 呼吸器系疾患 & & 1 & 1 \\
\hline 肺 癌 & 右肺切除 & 1 & 1 \\
\hline その他 & & 46 & \\
\hline 計 & & $236(72)$ & $17(16)$ \\
\hline
\end{tabular}


表 4 緊急手術症例

千葉大 2 外, 千葉社保 1966.9 1989.6

\begin{tabular}{|c|c|c|c|}
\hline 原 疾 患 & 術 & 症例数 & 直死例数 \\
\hline 消化器系疾患 & & 45 & 9 \\
\hline 食道異物 & 食道切開術 & 1 & \\
\hline 胃十二指腸潰瘍 & 胃切除術 & 2 & \\
\hline 十二指腸潰瘍穿孔 & 胃切除術・ドレナージ & 1 & \\
\hline 吻合部潰場 & 残胃再切除術 & 1 & 1 \\
\hline 胆囊炎 & 胆囊摘出術 & 1 & \\
\hline 小腸脂肪腫 & 回腸部分切除術 & 1 & \\
\hline 腸間膜血腫 & 開腹止血術 & 1 & \\
\hline 虫垂炎 & 虫垂切除術 & 16 & 1 \\
\hline 腹膜炎 & ドレナージ & 7 & 3 \\
\hline 腸閉塞症 & 癒着剝離術 & 7 & 2 \\
\hline 結腸軸捻転 & $\mathrm{S}$ 状結腸切除 & 1 & \\
\hline 上腸間膜動脈血栓症 & 試験開腹 & 2 & 2 \\
\hline 虫垂癌 & 虫垂切除術 & 1 & \\
\hline 痔 核 & 根治術 & 2 & \\
\hline 腸結核 & 試験開腹 & 1 & \\
\hline 心血管系疾患 & & 18 & 3 \\
\hline 心包炎・心タンポナーデ & 心包ドレナージ & 17 & 3 \\
\hline 鎖骨下静艆血栓症 & 血栓除去術 & 1 & \\
\hline 泌尿器系疾患 & & 3 & 1 \\
\hline 膀胱出血 & 膀胱切開 - 骨片除去術 & 2 & 1 \\
\hline 膿腎症 & 腎摘出術 & 1 & \\
\hline 整形外科系疾患 & & 2 & 2 \\
\hline 化膿性股関節炎 & ドレナージ & 1 & 1 \\
\hline 頸䯚膿瘍 & ドレナージ & 1 & 1 \\
\hline 産婦人科系疾患 & & 1 & \\
\hline 早 産 & Porro's 手術 & 1 & \\
\hline 脳外科系疾患 & & 3 & 1 \\
\hline 硬膜下 (外) 血腫 & 開頭術 & 3 & 1 \\
\hline & & 72 & 16 \\
\hline
\end{tabular}

急手術 27 例中 9 例 $33 \%$ で, 待期手術 26 例中 0 例 $0 \%$ に 対し高頻度であった（図 1 )。待期手術死亡の 1 例は, 肺 癌にて右肺全葉切除後, ドレナージ穿刺時胆汁性腹炎と なった症例であった。

術後合併症は, 待期的小手術であった 46 例を除き, 待 期手術は 118 例で検討した。緊急手術と合わせ 180 例中 の術後合併症は, 敗血症および創部感染各 9 例, 肺合併 症 8 例, 高力リウム血症 7 例, 不整脈 5 例, blood access の閉塞, 消化管出血各 3 例, 心不全, 低りン血症による 意識障害各 2 例, 肝不全, 縫合不全各 1 例であった.こ れを緊急手術と待期手術に分け検討すると，敗血症およ び創部感染は, 緊急手術 $9.7 \%$, 待期手術 $2.5 \%$, 肺合併 症はそれぞれ $8.9 \% ， 2.5 \%$ ，心不全は $2.8 \%$ (いずれも 糖尿病性腎症)，0\%，消化管出血は $2.8 \%, 0.8 \%$ で, 高
カリウム血症と不整脈はいずれも $3 \%$ 前後であった（図 2).

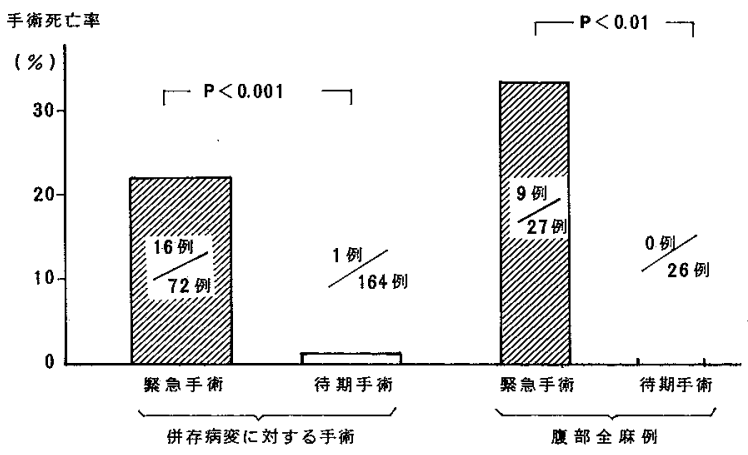

図 1 併存病変に対する手術成績 
術前検查値の検討では, 緊急手術 29 例, 待期手術 38 例 で検討すると，それぞれ，Ht は，19.8土7.5\%，28.8土 $7.4 \%$ ( $\mathrm{p}<0.001)$, 血清カリウムは, $4.9 \pm 1.1 \mathrm{mEq} / l, 4.2 \pm$ $0.6 \mathrm{mEq} / l(\mathrm{p}<0.01)$, 血清総蛋白は $6.7 \pm 1.1 \mathrm{~g} / \mathrm{d} l, 7.2 \pm$ $0.6 \mathrm{~g} / \mathrm{d} l(\mathrm{p}<0.05)$, BUN は, $74.5 \pm 22.1 \mathrm{mg} / \mathrm{d} l, 42.0 \pm$ $22.0 \mathrm{mg} / \mathrm{d} l \quad(\mathrm{p}<0.001)$, 血清クレアチニンは $12.7 \pm 3.8$ $\mathrm{mg} / \mathrm{d} l, 6.5 \pm 3.8 \mathrm{mg} / \mathrm{d} l(\mathrm{p}<0.001)$ であった。

2. 最近経験した緊急手術症例の検討

最近我々 は, 十二指腸潰瘍穿孔， $\mathrm{S}$ 状結腸軸捻転壊死， 絞抳性イレウス, 食道噴門癌・多発性十二指腸潰瘍穿通 の 4 例を経験した (表 5 )。症例 $1 ， 3 ， 4$ が糖尿病性腎 症例であった。術前合併症として, 片麻痺, 春損, 趾壊 疽，視力低下・昍下血があり，術前透析は，急性増悪の 症例 4 を除き，通常膜の透析器を用い，抗凝固剂として ヘパリンを用いた conventional 透析であった。術後初回 透析は, $1 \sim 2$ 病日に EVA 膜透析器を用いた少へパリ ン $(200 \mathrm{U})$ 透析を施行した。術後合併症は症例 1 で肺水 腫，心不全，Candidaによる皮下膿場，コアグラーゼ陰 性ブドウ球菌 (CNS) による肺炎, 症例 2 でメチシリン 耐性黄色ブドウ球菌（MRSA）による創部膿瘍，低リン 性意識障害，症例 3 で，心不全，肺水腫，消化管出血が 認められた。

症例 3 は，術前の基準体重が $52.2 \mathrm{~kg}$ で術後 $3 \mathrm{~kg}$ 下
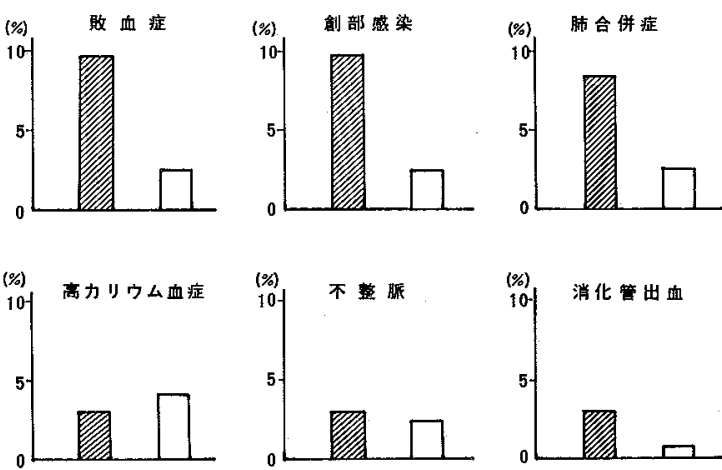

図 2 術後合併症の比較

緊急手術例 $(n=72)$ ， $\square$ 待期手術例 $(n=118)$

げて管理したが 5 病日に心不全，肺水腫となり ECUM にて $1 \mathrm{~kg}$ 除水にて改善を認めた（図 3 ). 症例 4 では, 術前に腎機能の急激な低下があり血液透析を施行した。 その後 $\mathrm{Ht}$ の急激な低下を認め食道噴門癌からの出血と 考之開胸開腹した。しかし，出血は多発性十二指腸潰場 によるもので一部胆囊壁に穿通していた，腎機能の低下 の原因はこれで，術後血液透析の必要はなかった．術後 10 病日に十二指腸潰瘍再出血によると思われる出血性 ショックで死亡した（図 4)。

表 5 最近の緊急手術症例

\begin{tabular}{|c|c|c|c|c|c|c|c|c|c|}
\hline & $\begin{array}{c}\text { 年齢 } \\
\text { 性 } \\
\end{array}$ & $\begin{array}{c}\text { 原疾患 } \\
\text { 透析歴 }\end{array}$ & $\begin{array}{l}\text { 手術疾患 } \\
\text { • } \\
\text { 術 式 }\end{array}$ & & $\begin{array}{l}\text { 们合併症 } \\
\text { 行検查值 } \\
\end{array}$ & 術前透析 & 術後初回透析 & 合併症 & 転帰（死因） \\
\hline 1 & $\begin{array}{l}58 \\
\dot{\mathrm{M}}\end{array}$ & $\begin{array}{l}\text { DN } \\
2 \mathrm{M}\end{array}$ & $\begin{array}{c}\text { DG 穿孔 } \\
\text { 胃切除， ドレナージ }\end{array}$ & $\begin{array}{l}\text { 左片麻 } \\
\mathrm{Ht} \\
\mathrm{S}-\mathrm{K} \\
\mathrm{UN} \\
\mathrm{Cr}\end{array}$ & $\begin{array}{r}26 \% \\
4.5 \mathrm{mEq} / l \\
100 \mathrm{mg} / \mathrm{d} l \\
9 \mathrm{mg} / \mathrm{d} l\end{array}$ & $\begin{array}{l}\text { 術前 } 3 \text { 病日 } \\
\text { Conventional HD } \\
\left(1.0 \mathrm{~m}^{2}\right) \\
3 \text { 時間 }\end{array}$ & $\begin{array}{l}\text { 術後 1 病日 } \\
\left\{\begin{array}{l}\text { EVA 膜 }\left(1.0 \mathrm{~m}^{2}\right) \\
\text { 少へパリン } \\
3 \text { 時間 }\end{array}\right.\end{array}$ & $\begin{array}{l}\text { 肺水腫 } \\
\text { 心不全 } \\
\text { 皮下膿瘍 } \\
\text { (Candida) } \\
\text { 肺炎 } \\
\text { (CNS) }\end{array}$ & 生 \\
\hline 2 & $\begin{array}{l}60 \\
\dot{\mathrm{M}}\end{array}$ & 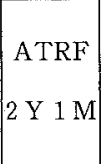 & $\begin{array}{c}\mathrm{S} \text { 状結腸軸揄転, 壊死 } \\
\text { S 状結腸切除 }\end{array}$ & $\begin{array}{l}\text { 苓損, } \\
\mathrm{Ht} \\
\mathrm{S}-\mathrm{K} \\
\mathrm{UN} \\
\mathrm{Cr}\end{array}$ & \begin{tabular}{|r|} 
F半身麻瘏 \\
$26 \%$ \\
$4.3 \mathrm{mEq} / l$ \\
$49 \mathrm{mg} / \mathrm{d} l$ \\
$6.7 \mathrm{mg} / \mathrm{d} l$
\end{tabular} & $\begin{array}{l}\text { 術前 } 1 \text { 病日 } \\
\text { Conventional HD } \\
\left(2.0 \mathrm{~m}^{2}\right) \\
3 \text { 時間 }\end{array}$ & $\begin{array}{l}\text { 術後 2病日 } \\
\left\{\begin{array}{l}\text { EVA 膜 }\left(1.5 \mathrm{~m}^{2}\right) \\
\text { 少へパリン } \\
3.5 \text { 時間 }\end{array}(200 \mathrm{U})\right.\end{array}$ & $\begin{array}{l}\text { 創部膿瘍 } \\
\text { (MRSA) } \\
\text { 意識障害 } \\
\text { (低 P性) }\end{array}$ & 生 \\
\hline 3 & $\begin{array}{l}72 \\
\dot{\mathrm{M}}\end{array}$ & $\mid \begin{array}{c}\mathrm{DN} \\
2 \mathrm{Y} 5 \mathrm{M}\end{array}$ & $\begin{array}{c}\text { 絞扼性イレウス } \\
\text { • } \\
\text { 絞扼解除 }\end{array}$ & $\begin{array}{l}\text { 趾壊瘨 } \\
\mathrm{Ht} \\
\mathrm{S}-\mathrm{K} \\
\mathrm{UN} \\
\mathrm{Cr}\end{array}$ & $\begin{array}{r}18.8 \% \\
5.4 \mathrm{mEq} / l \\
82 \mathrm{mg} / \mathrm{d} l \\
7.4 \mathrm{mg} / \mathrm{d} l\end{array}$ & $\begin{array}{l}\text { 術前 } 1 \text { 病日 } \\
\text { Conventional HD } \\
\left(2.0 \mathrm{~m}^{2}\right) \\
4 \text { 時間 } 30 \text { 分 }\end{array}$ & $\begin{array}{l}\text { 術後 } 2 \text { 病日 } \\
\left\{\begin{array}{l}\mathrm{EVA} \text { 膜 } \\
\text { 少へパリン } \\
\\
4 \text { 時間 }\end{array}(200 \mathrm{U})\right.\end{array}$ & $\begin{array}{l}\text { 心不全 } \\
\text { 肺水腫 } \\
\text { 消化管出血 }\end{array}$ & 生 \\
\hline 4 & $\begin{array}{l}48 \\
\dot{\mathrm{M}}\end{array}$ & $\left.\begin{array}{c}\text { DN } \\
11 \text { 日 } \\
(3 \text { 回) } \\
\text { (急性) } \\
\text { 増悪 }\end{array}\right)$ & 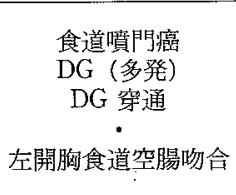 & $\begin{array}{l}\text { 視力低 } \\
\text { 吐血・- } \\
\mathrm{Ht} \\
\text { S-K } \\
\mathrm{UN} \\
\mathrm{Cr}\end{array}$ & $\begin{array}{l}25 \% \\
4.4 \mathrm{mEq} / l \\
165 \mathrm{mg} / \mathrm{d} l \\
5.8 \mathrm{mg} / \mathrm{d} l\end{array}$ & $\begin{array}{l}\text { 術前 } 5 \text { 病日 } \\
\left\{\begin{array}{l}\mathrm{EVA} \text { 膜 } \\
\text { 少ヘパリン } \\
3 \text { 時間 }\end{array}(200 \mathrm{U})\right.\end{array}$ & な & $\begin{array}{l}\text { 消化管出血 } \\
\text { ショック }\end{array}$ & $\begin{array}{c}\text { 真 死 } \\
\text { (消化管出血) }\end{array}$ \\
\hline
\end{tabular}

DN : 糖尿病性腎症, ATRF : 外傷後慢性腎不全, DG：十二指腸潰瘍, CNS : コアグラーゼ陰性ブドウ球菌, MRSA：メチシリン而性 黄色ブドウ球菌 


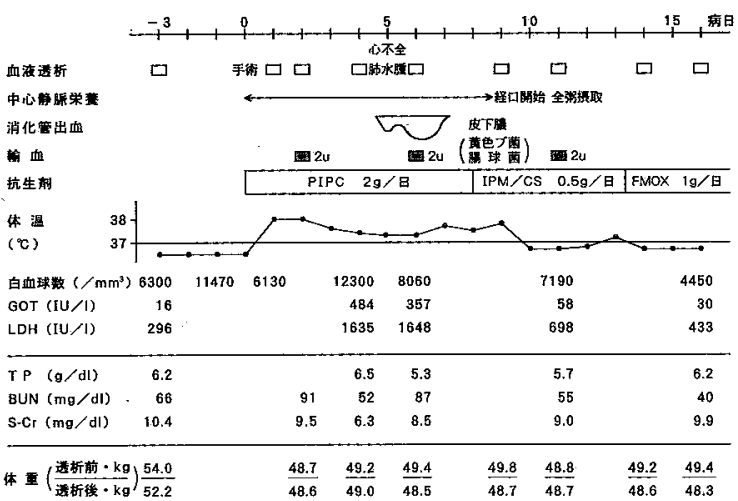

図 3 症例 $3: 72$ 歳男性. 糖尿病性腎症, 絞扼性 イレウス

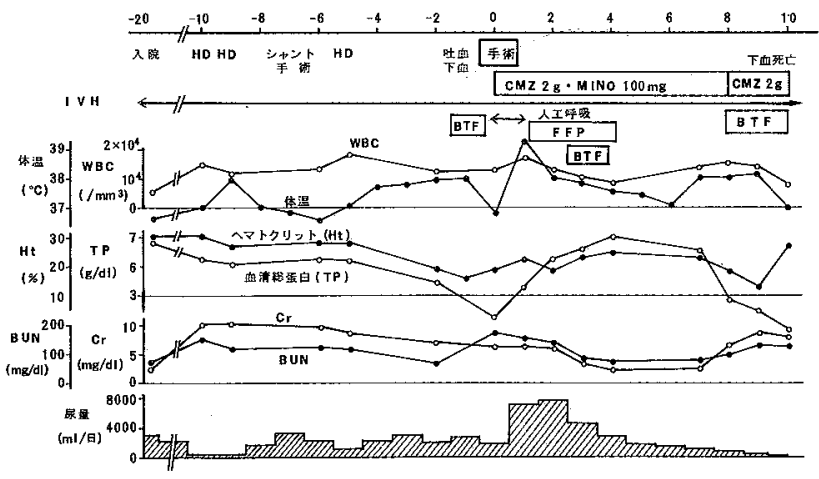

図 4症例 4:48 歳男性。糖尿病性腎症, 食道噴 門癌，多発性十二指腸潰瘍おるび穿通，左 開胸食道空腸吻合術施行

3. 術後初回透析時の低分子ヘパリン使用経験

図 5 に示すごとく，非手術例の ACT 值は透析前生体 内で 150 170 秒 (平均 $159 \pm 8$ 秒) であり, 回路内では, 透析開始 1 時間で動脈側が $153 \pm 8$ 秒, 静脈側が $159 \pm 6$ 秒, 終了直前で動脈側が $141 \pm 7$ 秒, 静脈側が $144 \pm 5$ 秒 であった。シャント穿刺部の止血時間は $3 \sim 10$ 分 (平均 $5 \pm 3$ 分）であった。

これに対し術後初回透析例では，シャント対側静脈血 で透析前 $156 \pm 16$ 秒，透析 1 時間 $143 \pm 3$ 秒， 3 時間後 $142 \pm 4$ 秒であった. 回路内では，透析開始 1 時間で動脈 側 $156 \pm 16$ 秒，静脈側 $168 \pm 11$ 秒であり，終了直前で動 脈側 $151 \pm 18$ 秒，静脈側 $155 \pm 14$ 秒であった.シャント 穿刺部止血時間は $3 \sim 5$ 分 (4.3 00.8 分) であった.

食道癌術後初回透析は FUT-175 を用いたが，シャン 卜対側静脈血の ACT は，透析前 128 秒，開始後 3 時間 145 秒，終了後 1 時間 146 秒であり，回路内では，開始後 1 時間で, 動脈側 144 秒, 透析器直前 302 秒, 静脈側 197

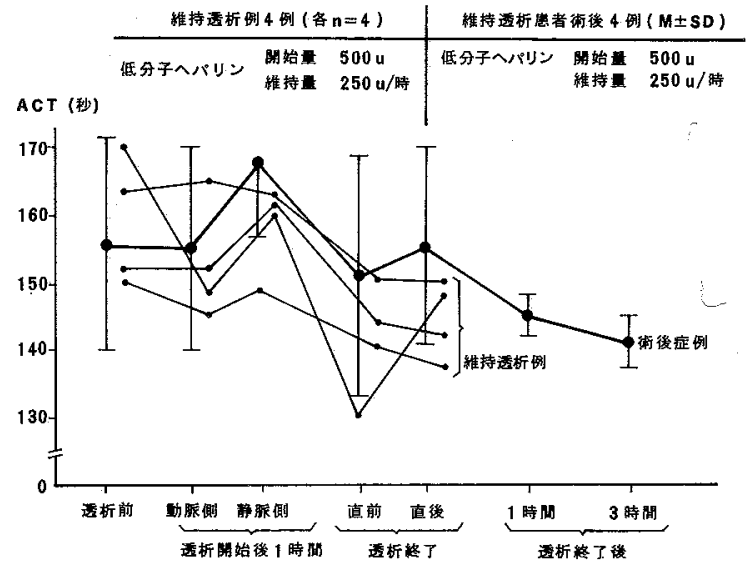

図 5 低分子へパリンを用いた血液透析時のアク ス夕一法凝固時間 $(\mathrm{ACT})$ の変化

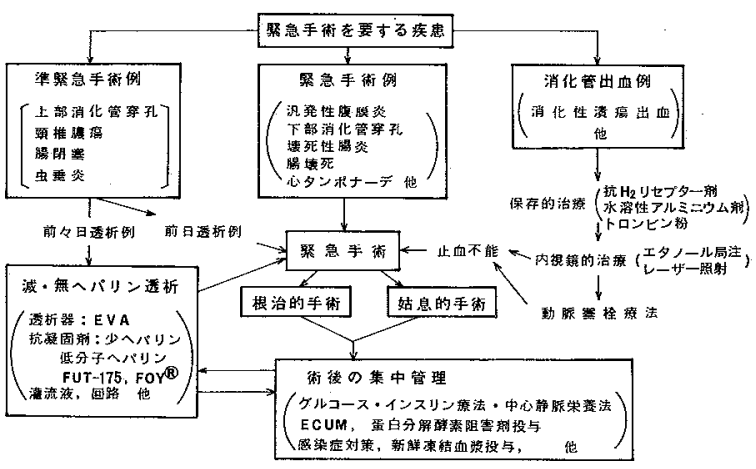

図 6 慢性透析患者緊急手術例の対策

秒であり, 開始後 3 時間でも, 動脈側 152 秒, 透析器直 前 310 秒, 静脈側 197 秒であった。透析器内凝血も, 術 後出血も認めなかった。

\section{考案}

緊急手術の手術成績が悪いのは，その病態が，感染や 出血に関連しているためで, septic MOF で死亡するこ とが多い3).したがってその病態を把握したうえで, 術前 準備, 術後管理, 血液浄化法の時期と方法の選択等が重 要となる(図6).

いわ功る緊急手術を，緊急手術と準緊急手術に分けて 考えている。緊急手術は，12 時間以内に重症感染症や ショックを惹起する可能性の高い疾患例で，汎発性腹膜 炎, 下部消化管穿孔, 壊死性腸炎, 腸壊死, 心タンポナー デ等であり，これは全身状態が悪くとも早急に手術を施 行し，原因を除去後，全身管理により状態の改善を目ざ すべきである.上部消化管穿孔では, 穿孔後 12 時間まで は高酸であるため表皮性ブドウ球菌 (CNS) が主な菌で 
あり，ただちに敗血症や汎発性腹膜炎に至ることは少な いといわれている.したがって, 上部消化管穿孔, 頸椎 膿場, 腸閉塞, 虫垂炎では, onset からの診断が遅れてい なければ，準緊急手術と考元，術前透析等全身管理施行 後手術をして良いと考えている. 最近の透析療法の進歩 により，日常的には十分な透析が行われており，準緊急 手術でも前日透析なら, 術前透析は必要ないものと考え ている.

緊急手術を要する疾患を早期に診断することが重要 で, 日常診療が大切と考えている. 透析患者では, 透析 中に消化器症状を訴えることが多く, 常に他疾患の存在 を念頭に置く必要がある8)。

減・無へパリン透析の進歩はめざましく, 図 7 亿抗凝 固剂, 抗血小板剂の血小板・凝固・線溶系における作用 点を示す。再生セルロース系膜，セルロースアセテート 膜等の親水性膜に比して, PMMA, PAN, ポリスルホン の疎水性膜では9"), 血液との接触によって血液中の蛋白 質が材料表面に吸着され, その蛋白質は変性し, 血小板 因子等の放出を促進する ${ }^{10)}$.このとき, 血液凝固因子も同 様に吸着されXII因子の活性化から血液凝固が開始され， 血液透析における凝血阻止には，血液凝固因子系と血小 板系の両方に対する対策が必要となる ${ }^{10)}$. EVA膜は, 親 疎水性膜とされ，抗血小板粘着抑制作用を最も有してお $\eta^{9)}$, 我々は, 術後の初回から 3 回までの透析は 200 300 U のへパリンを用いた EVA 膜透析を施行しており，空 気泡除去と, 血液と空気の接触を防げば, 問題なく透析 が施行され，後出血例の経験もない。

血小板機能抑制剤には, $\mathrm{PGI}_{2}$ や $\mathrm{PGE}_{1}$ 等のプロスタ グランジン製剤， adenyl cyclase 賦活作用のチクロピジ ン, cyclooxygenase 抑制作用のアスピリンやインドメ

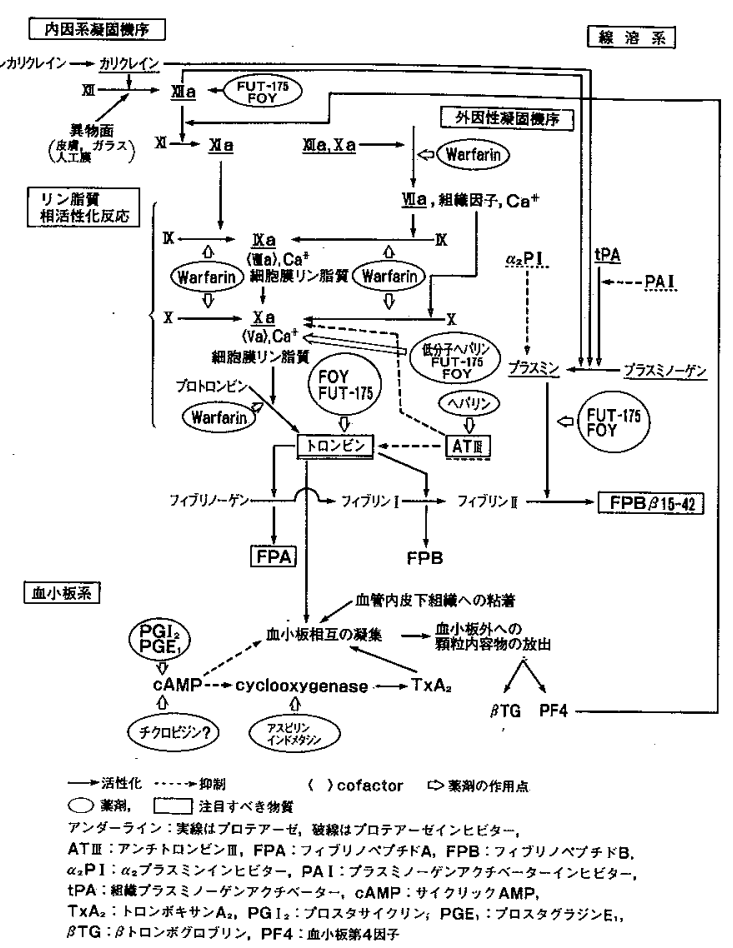

図 7 血小板・凝固・線溶系と薬剤の作用点

タシンがある(表 6 )。これらの薬剮は, conventional な 透析でヘパリンの減量には有用でも, 緊急手術に関連し た透析には適応がない。乙れに対し凝固系阻害剤は，低 分子へパリン, gabexate mesilate (FOY), FUT-175 が 有用である(表 7 ). 今回の我々の低分子へパリン使用に よる透析では, 開始量 $500 \mathrm{U}$, 維持量 $250 \mathrm{U} /$ 時で後出血.

表 6 血小板機能㧕制剤

\begin{tabular}{|c|c|c|c|c|c|c|}
\hline 薬 郕 & 薬理作用 & $\begin{array}{c}\text { 血小板 } \\
\text { 凝集抑制 }\end{array}$ & $\begin{array}{l}\text { 出血時間 } \\
\text { 延 長 }\end{array}$ & $\begin{array}{l}\text { 血小板 } \\
\text { 寿命延長 }\end{array}$ & 半減期 & 副作用, その他 \\
\hline Aspirin & $\begin{array}{l}\text { Cyclooxygenase } \\
\text { 抑制 }\end{array}$ & $(+)$ & $(+)$ & $(-)$ & 1週間 & $\begin{array}{l}\text { ライ症候群に注意。 } \\
\text { 過敏症, 血液異常および } \\
\text { 胃腸症状等. }\end{array}$ \\
\hline Ibuprofen & $\begin{array}{l}\text { Cyclooxygenase } \\
\text { 㧕制 }\end{array}$ & $(+)$ & $(+)$ & $(-)$ & 6 時間 & $\begin{array}{l}\text { ショック, 血液異常抢よ } \\
\text { び消化性潰湯等. }\end{array}$ \\
\hline Indomethacin & $\begin{array}{l}\text { Cyclooxygenase } \\
\text { 揤制 }\end{array}$ & $(+)$ & $(+)$ & $(-)$ & 24 時間 & $\begin{array}{l}\text { 消化性潰瘍, 直腸炎, 血 } \\
\text { 液異常および皮症症 } \\
\text { 等. }\end{array}$ \\
\hline $\begin{array}{l}\text { Prostacyclin } \\
\left(\mathrm{PGI}_{2}\right)\end{array}$ & $\begin{array}{l}\text { Adenylate cyclase } \\
\text { 賦活 }\end{array}$ & $(+)$ & $(+)$ & $(+)$ & 10 分 & $\begin{array}{l}\text { 血圧低下, 頭痛, および } \\
\text { 顔面紅潮等。 }\end{array}$ \\
\hline $\mathrm{PGE}_{1}$ & $\begin{array}{l}\text { Adenylate cyclase } \\
\text { 賦活 }\end{array}$ & $(+)$ & $(+)$ & $(+)$ & 0.33 分 & $\begin{array}{l}\text { 血小板凝集抑制効果が血 } \\
\text { 管拡張作用より弱い. }\end{array}$ \\
\hline Ticlopidine & $\begin{array}{l}\text { Adenylate cyclase } \\
\text { 賦活 }\end{array}$ & $(+)$ & $(+)$ & $(+)$ & 4 日 & $\begin{array}{l}\text { 作用発現まで数日を要す } \\
\text { る。 }\end{array}$ \\
\hline
\end{tabular}


表 7 凝固系阻害剂

\begin{tabular}{|c|c|c|c|c|c|c|}
\hline 薬 剂 & 分子量 & 薬理作用 & 半隇期 & 副作用・その他 & 血液透析時投与量 & DIC 時投与量 〜 \\
\hline ヘパリン & $\begin{array}{l}10,000 \\
\sim 15,000\end{array}$ & $\begin{array}{l}\text { AT IIIを介して主として } \\
\text { 抗トロンビン作用 } \\
\text { 抗Xa 作用 } \\
\end{array}$ & 45 分 & \multirow{2}{*}{$\begin{array}{l}\text { アレルギー, 脂質・骨 } \\
\text { 代謝, 動脈硬化 } \\
\text { AT III減少, 血小板活 } \\
\text { 性化 } \\
\text { 拮抗剤はプロタミン }\end{array}$} & $\begin{array}{l}1,000 \sim 2,000 \mathrm{U} \\
\text { (開始時) } \\
500 \sim 1,000 \mathrm{U} / \text { 時 }\end{array}$ & $6,000 \sim 12,000 \mathrm{U} /$ 日 \\
\hline 低分子へパリン & $\begin{array}{l}4,000 \\
\sim 6,000\end{array}$ & 抗 Na 作用を強く有する & 90 分 & & \begin{tabular}{|c|}
$15 \sim 30 \mathrm{U} / \mathrm{kg}$ \\
(開始時) \\
$7.5 \sim 10 \mathrm{U} / \mathrm{kg} /$ 時
\end{tabular} & $75 \mathrm{U} / \mathrm{kg} /$ 日 \\
\hline $\begin{array}{l}\text { Argipidine } \\
\text { (MD 805) }\end{array}$ & 527 & $\begin{array}{l}\text { トロンビンに対し可逆的 } \\
\text { 特異的に阻害 }\end{array}$ & 30 分 & 時に止血困難 & $\begin{array}{l}10 \sim 40 \mathrm{mg} / \text { 時 } \\
\text { 単独使用 }\end{array}$ & $\begin{array}{l}23 \sim 83 \mathrm{mg} / \text { 日 } \\
(0.7 \pm 0.2 \mu \mathrm{g} / \mathrm{kg} / \text { 分 })\end{array}$ \\
\hline FOY & 417 & 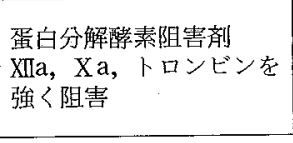 & $2 \sim 3$ 分 & 静脈炎 & $\begin{array}{l}1,500 \sim 2,000 \mathrm{mg} / \text { 時 } \\
800 \mathrm{mg} / \text { 時 } \\
\text { ペ゚リン } \\
100 \sim 200 \mathrm{U} / \text { 時 }\end{array}$ & $20 \sim 40 \mathrm{mg} / \mathrm{kg} /$ 日 \\
\hline $\begin{array}{l}\text { Nafamostat } \\
\text { (FUT-175) }\end{array}$ & 540 & 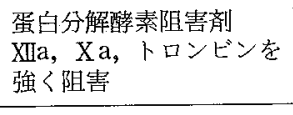 & $5 \sim 8$ 分 & 消化器症状 & $\begin{array}{l}20 \sim 50 \mathrm{mg} / \text { 時 } \\
\text { 単独使用 }\end{array}$ & $0.1 \sim 0.2 \mathrm{mg} / \mathrm{kg} /$ 時 \\
\hline クエン酸 $\mathrm{Na}$ & 214 & $\begin{array}{l}\text { CaHキレート } \\
\text { 血小板活性化も防止 }\end{array}$ & $\begin{array}{l}\text { 体外循環 } \\
\text { 路の 及 }\end{array}$ & 低 Ca 血症 & 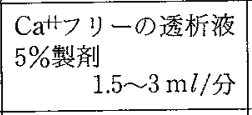 & \\
\hline Warfarin & 346 & $\begin{array}{l}\text { ビタミン依存性凝固因子 } \\
\text { (II, VII, IX, X)を強く } \\
\text { 阻害する }\end{array}$ & $\begin{array}{l}36 \sim \\
48 \text { 時間 }\end{array}$ & $\begin{array}{l}\text { 作用発現まで数日を要 } \\
\text { する。剂はビタミン } \mathrm{K} \\
\text { 拮抗 }\end{array}$ & $\mid \begin{array}{l}0.5 \sim 4 \mathrm{mg} / \text { 日 } \\
\text { ペリン経口 }\end{array}$ & \\
\hline
\end{tabular}

もなく十分な術後初回透析ができた。

FOY と FUT-175 は，ともにアンチトロンビンIIIを 必要としないで，トロンビンに対する強い拮抗的阻害作 用を有している ${ }^{11,12)}$. FOY は, 半減期が短く, 1 時間に $1,500 \sim 1,600 \mathrm{mg}$ 投与する必要があり, $11 \%$ に嘔気，嘔吐 等の副作用を認めている ${ }^{11)}$.これに対し FUT-175 は, 半滅期が $5 \sim 8$ 分と手頃で初期投与 $20 \mathrm{mg}$, 維持投与 20 〜 $50 \mathrm{mg}$ /時で体外循環が可能で ${ }^{12)}$, 我々の食道癌術後初 回透析では維持投与 $20 \mathrm{mg}$ で十分であった.さらに FUT-175 の $50 \mathrm{mg}$ の製剂が比較的安価で使い易くなっ ている. 我々は緊急手術直前の透析, 術後透析や術後の 持続的血液濾過には FUT-175 が有用と考元使用してい る.

このように，術前後の血液透析は，十分に安全に行え るようになって扔り，症例各々の状態に合わせて選択し 施行すれば良いと考えている。

術後の集中治療については，グルコース・インシュリ ン療法, 中心静脈栄養法, ECUM, 蛋白分解酵素阻害剂, 新鮮凍結血漿投与が有用である ${ }^{13)}$. 近年, 術後感染症の中 でもメチシリン耐性黄色ブドウ球菌 (MRSA) 感染が問 題となってきている ${ }^{14,15)}$. 予防的抗生剂投与も第 3 世代 セフェム凨では, CNS, MRSA, 腸球菌, 緑膿菌, Candida の感染例が多く認められ, 今回の検討症例の中にもCandida, CNS, MRSA 感染を認めた。透析患者とくに緊急 手術例では, 免疫能の低下が考えられ，予防的抗生剤の
選択や院内感染予防対策が重要と思われる。

本邦に怙ける 1987 年 12 月 31 日現在の透析患者数は 8 万人を超え, 年々 7,000 人ずつ増加している ${ }^{16)} .1987$ 年 の導入患者数は 14,699 人で, このうち糖尿病性腎症患者 は 3,226 人 $22.1 \%$ でありその割合は年々増加している。 全透析患者に占める糖尿病性腎症患者は 9,335 人で $11.7 \%$ あった。したがって今回検討したごとく，糖尿 病性腎症例の併存病変に対する緊急手術対策が必要と なっている。

糖尿病の特徵は, 代謝異常と循環動態の異常にあり, 腎機能正常例でも手術治療上の問題を多く有してい $ろ^{17)}$. 腎機能正常者の術前の目標は, risk factor の是正 や 1 日尿糖 $10 \mathrm{~g}$ 以下等であり, 糖尿病性腎症例では, 腎 機能の低下により腎でのインシュリン不活化が少なくな りインシュリン投与をしなくても血糖コントロールが可 能な例が多い.出口ら ${ }^{18)}$ の腎障害のない糖尿病例 67 例の 検討では, 重症例 6 例に全例術前合併症を認め, 術後合 併症のない例は 1 例であった。このことから糖尿病患者 の手術適応に対し, 赤木ら ${ }^{19}$ は, 血糖調節とともに主要臓 器の機能障害を調べ, 手術内容を勘案して手術適応条件 を判断することが必要で，時には侵襲量の少ない姑息的 手術を選ばれなければならないことが少なくないと述べ ている，我々が経験した最近の緊急手術 4 例では，全例 が術前合併症を有しており, 術後全例に合併症を認めた。

糖尿病性腎症例の透析予後は不良で, 4 年生存率は 
46\%で慢性腎炎の $75 \%$ よ低い.このことも糖尿病性腎 症例の手術適応の選択を困難にしている。我々は，糖尿 病性腎症例で消化管恵性腫瘍手術に際しては，手術侵襲 による影響と, 導入後の透析予後の不良から, 縮小手術・ 重点郭清で良いのではないかと考元ている ${ }^{20)}$. 緊急手術 においても感染や壊死巣の除去はしなければならない が，その方法の中で手術侵襲が少なく安全性の高い手術 を目ざす必要があると考えている。

\section{結語}

1. 透析患者の手術死亡率は，緊急手術で $22 \%$, 待期 手術で $0.6 \%$ あった。術後合併症も緊急手術で，敗血 症, 創部感染, 肺合併症, 消化管出血が高頻度であった。

2。最近の糖尿病性腎症例の緊急手術では，全例飞術 前合併症と術後合併症を認めた。術後合併症には心不全 や術後感染症が多く，水分管理や院内感染予防が重要で ある。

3. 緊急手術では術後透析，準緊急手術では，前日透 析なら術後透析，前々日透析なら術直前透析が良いと思 われる。術後透析および術直前透析では，低分子へパリ ンや，FUT-175を用いた透析か，EVA 膜少へパリン透 析が有用である。

本論文の要旨は, 第 34 回日本透析療法学会総会 (1989) の ワークショップ「慢性透析患者の緊急手術時の対策」にて発 表した。

\section{文献}

1）太田和夫：総論 (1) 医師の立場から。臨牀透析 5 ： $1115-1120,1989$

2) 足立悦子：総論 (2) 看護婦の立場から。臨牀透析 5： 1121-1126, 1989

3）添田耕司，田畑陽一郎，林 春幸，中市人史，今関 英男，朝長 毅，吉田正美，西郷健一，小高通夫， 磯野可一：透析外科栄養法における尿酸代謝の検 討. 日本静脈・経腸栄養研究会誌 $4: 136-139,1989$

4）添田耕司，小高通夫，平澤博之，小林弘忠，菅井桂 雄, 林 春幸, 小林 進, 室谷典義, 伊藤 靖, 大 島郁也, 磯野可一, 嶋田俊恒, 桜井信也, 織田成人： 透析患者に対する外科手術上の問題点と対策一緊急 手術および消化器癌手術を中心に一. 透析会誌 19 ： 263-275, 1986

5）小高通夫，添田耕司，田栗正章：血液浄化法の適応 患者の推移と将来予測。臨床医 $11 ： 104-106 ， 1985$

6）小高通夫，添田耕司，嶋田俊恒：糖尿病性腎症の現
洗. 臨牀透析 1:531-539, 1985

7）信楽園病院腎センター：凝固時間の測定法と評価. 平沢由平監修，透析療法マニュアル第 3 版，p 144 -145，日本メディカルセンター，東京，1989

8）古川俊隆, 本田善九郎, 丸山正董, 松田哲郎, 村田 升, 加藤博久, 國井紀彦, 梶原 広, 青木敏夫, 小 暮哲夫, 杉本陽子, 田口幸江：慢性透析患者に対す る緊急手術の経験。臨牀透析 $5 ： 749-754 ， 1989$

9) 内藤秀宗, 宮崎哲夫, 長坂 肇 : 無抗凝固剂透析. 臨牀透析 $5: 1871-1875,1989$

10）前田憲志：内服抗凝血薬の併用。臨牀透析 5 ： 1883-1888, 1989

11）副島秀久: Gabexate mesilate (FOY). 臨牀透析 $5: 1851-1854,1989$

12）秋沢忠男, 新倉一彦, 越川昭三: Nafamostat mesilate (FUT-175)。臨牀透析 $5: 1855-1860,1989$

13）小高通夫, 田畑陽一郎，添田耕司，林 春幸，今関 英男, 嶋田俊恒, 桜井信也，岡 龍弘，水口公信： 透析患者の手術の術前・術中・術後管理。臨牀透析 3:1571-1582，1987

14）添田耕司, 小野田昌一, 吉田正美, 磯野可一, 菅野 治重, 渡辺正治：消化器外科における Methicillin -resistant Staphylococcus aureus 感染とその流行. 臨床外科 $44: 269-273,1989$

15）添田耕司，小野田正一，神津照雄，奥山和明，小出 義雄, 磯野可一: Methicillin-resistant Staphylococcus Aureus 感染の特徵の意義。日外会誌 $90: 955,1989$

16）小高通夫：わが国の透析療法の現況 (1988)。透析会 誌 22：221-304, 1989

17）後藤由夫, 鈴木研一：糖尿病患者の病態生理一手術 と関連して一。臨床外科 $41: 281-286,1986$

18）出口久次，龍礼之助，北原信三，村国 均，名越大 起, 椿秀三千, 継 行男: 糖尿病合併症例の手術治 療の問題点.日臨外医会誌 $44 ： 327-331 ， 1983$

19）赤木正信，前野正伸，三宅 孝，山崎洋二，木原信 市：糖尿病患者の評価と手術適応。臨床外科 41 ： 287-294，1986

20）添田耕司，小高通夫，田畑陽一郎，林 春幸，小野 田昌一, 神津照雄，奥山和明，小出義雄，荻野幸伸， 磯野可一, 入江康文, 嶋田俊恒：透析患者の消化管 悪性腫瘍の現状と治療。䢴牀透析 4:1591-1598, 1988 